\title{
Travel Through Time: From 9/11 to COVID-19, Parallel Predictive Analysis of Travel Marketing
}

\author{
Hannah Gilliam* \\ Gainey School of Business, Spring Arbor University, Spring Arbor, MI \\ bttps:/ / doi.org/10.33697/ ajur.2020.029 \\ Student: hannabrg@gmail.com*
}

\begin{abstract}
The events of 9/11 drastically changed the state of the nation across many industry sectors, with the tourism industry among those most affected. Following that horrific day, the nation experienced heightened security measures and protocol, such that the travel industry and travelers would never look the same. People were fearful and anxious, and the tourism industry had to take quick, effective measures to evaluate the consumer response, set a marketing strategy, and promote within a changed national ethos and expectations. COVID-19 is a similar catastrophic, global, and long-term crisis that set our nation on a similarly drastic change in practice and protocol; fear and anxiety were higher than ever. COVID-19 and 9/11 are highly comparable in their market response. By comparing the two events and analyzing the consumer response and advertising messaging, specifically during the stay at home order, a theme and direction for messaging within the travel industry post-COVID-19 can be predicted based on the culture and spirit of The American Dream, confidence in safety, we are in this together, support local tourism, explore your city in a new way, and connect with those you missed.
\end{abstract}

\section{KEYWORDS}

COVID-19; 9/11; Post-pandemic; Advertising; Travel; Prediction; Messaging; Consumer Response; Marketing; Analysis

\section{INTRODUCTION}

Comparing 9/11 to COVID-19

External shocks, 9/11, and COVID-19 are comparable because they represent serious crises in consumer confidence over matters of safety and security across a broad spectrum of culture, economics, and travel. According to the official White House statement, "[on] March 11, 2020, the World Health Organization announced that the COVID-19 outbreak could be characterized as a pandemic, as the rates of infection continue to rise in many locations around the world and across the United States." Then, on March 13, President Donald Trump declared that the United States of America was in a National State of Emergency. After 9/11, President George W. Bush called a National State of Emergency due to terrorist attacks. These events led to an emergency declaration, which provides the legal justification for civil authority to enlist short term rules and requirements. However, this alone does not prove that these two events are comparable.

Both 9/11 and COVID-19 caused emotional distress and a crisis. The definition of a crisis is "“[a] serious incident affecting, for example, human safety, the environment or product or corporate reputation — and which has either received or been threatened by adverse publicity". $19 / 11$ was a direct threat to the safety of the United States. The attacks on 9/11 were received as a warning and caused a great turning point in the state of our nation, leading to fear and increased travel security. People were fearful for our country, for their lives, their families' lives, and fearful of flying. COVID-19 is a crisis too, first, the public health of our nation and the world. More than that, it is a crisis to the environment and to corporate reputation. Due to the economic crash, the second quarter was the worst of any quarter since recorded numbers with a Gross Domestic Product contraction at an annualized rate, ${ }^{2}$ there are many unknowns among the environmental and corporate worlds. People are once again fearful for their lives, their families' lives, and fearful of flying.

Bradley Johnson compiled a list of statements from an article written in 2001 after 9/11 regarding the government and public response to the crisis, ${ }^{3}$ and there are strong COVID-19 parallels:

\begin{tabular}{|l|l|}
\hline 9/11 Response & COVID-19 Parallel \\
\hline "There is one word for ad spending: uncertain." 3 & $\begin{array}{l}\text { Advertising, while still being pushed during the stay at home } \\
\text { order, had changed drastically. Companies were releasing } \\
\text { homemade ads, featuring employees filming themselves at } \\
\text { home. There is an unknown end to this pandemic, and firms }\end{array}$ \\
\hline
\end{tabular}




\begin{tabular}{|c|c|}
\hline & $\begin{array}{l}\text { do not know when to expect to increase their marketing and } \\
\text { advertising again. Microsoft Teams released a commercial } \\
\text { featuring their employees around the world, filmed from } \\
\text { home, speaking on how Microsoft Teams allowed them to } \\
\text { continue working. }\end{array}$ \\
\hline $\begin{array}{l}\text { "The terrorism attack also led to cancellations of sporting } \\
\text { events." } 3\end{array}$ & $\begin{array}{l}\text { During the initial wave of the COVID-19 pandemic, the } \\
\text { NBA season was canceled, and the Summer Olympics } 2020 \text { in } \\
\text { Tokyo was postponed to } 2021 \text {. }\end{array}$ \\
\hline $\begin{array}{l}\text { "The commissioner of baseball canceled all Major League } \\
\text { games. The Emmy Awards were postponed. Broadway shows } \\
\text { were shuttered".3 }\end{array}$ & $\begin{array}{l}\text { Many of the MLB games have been canceled, including spring } \\
\text { games and training. }{ }^{5} \text { NFL drafts were virtual. }{ }^{6} \text { Many award } \\
\text { shows were rescheduled, including the Pulitzer Prize, the } \\
\text { Emmys, and the Tonys. Broadway shows were all shut down. }{ }^{7}\end{array}$ \\
\hline $\begin{array}{l}\text { "Movie studios will make some marketing cutbacks in the } \\
\text { short term as they postpone releasing some films with } \\
\text { terrorist or violent content." } 3\end{array}$ & $\begin{array}{l}\text { We have yet to see fully how movie studios will change } \\
\text { marketing due to the material and subject matter of a movie; } \\
\text { however, many studios proceeded forward with online and } \\
\text { streaming services for a virtual premiere of a film. For } \\
\text { example, in early September, Disney Plus did a virtual } \\
\text { premiere of the new live-action Mulan. }^{8}\end{array}$ \\
\hline $\begin{array}{l}\text { "The travel category faces dim near-term prospects given } \\
\text { terrorism and economic woes." } 3\end{array}$ & $\begin{array}{l}\text { Travel was shut down except for specific cases, and borders } \\
\text { across the world were closed. }{ }^{9}\end{array}$ \\
\hline $\begin{array}{l}\text { "Dozens of conventions and trade shows were canceled this } \\
\text { month due to the terrorist attacks in New York and } \\
\text { Washington:" } 3\end{array}$ & $\begin{array}{l}\text { The Las Vegas Trade Show was shut down, and many state } \\
\text { fairs were canceled. }{ }^{10} \text { Oktoberfest, in Germany, was canceled } \\
\text { for } 2020 .{ }^{11} \text { The historic St. Patrick's Day parade in Dublin, } \\
\text { Ireland was canceled in } 2020 . .^{12}\end{array}$ \\
\hline "Video conferencing [is rising] as some are not ready to fly." 3 & $\begin{array}{l}\text { Zoom, Webex, and other video conferencing media are in use } \\
\text { every day across the globe. Apps for video conferencing hit a } \\
\text { high download rate of } 62 \text { million one week in March, } 2020 .{ }^{13}\end{array}$ \\
\hline
\end{tabular}

Table 1. 9/11 and COVID-19 parallel cultural comparisons.

\section{METHODS AND PROCEDURES}

Regarding the current state of the economy and the world, this study examines how the COVID-19 pandemic will affect the travel industry and how the industry will promote, advertise, and ensure confidence in their consumers. To confidently predict what will happen, it is important to look to another time when the travel industry faced consumers fearing for their safety. Through peer reviews and case studies, research was drawn together on the 9/11 terrorist attacks and their advertising effects.

\section{RESULTS}

Company Approaches

Crisis Strategies: A Comparison

The attacks on $9 / 11$ were a crisis. When dealing with a crisis, there are a few ways to identify the crisis and then decide how to proceed. Evans \& Elphick from International Journal of Tourism Research, ${ }^{1}$ article "Models of crisis management: an evaluation of their value for strategic planning in the international travel industry" discuss these differences.

\begin{tabular}{|l|l|l|l|}
\hline Seymour and Moore & Response & Booth (1993) & Response \\
\hline $\begin{array}{l}\text { The 'Cobra' type of crisis is } \\
\text { sudden, for example, a } \\
\text { disaster, which may come as a } \\
\text { shock (e.g., September 11) }\end{array}$ & $\begin{array}{l}\text { Defensive response with } \\
\text { reliance on the known and } \\
\text { trusted }\end{array}$ & $\begin{array}{l}\text { Sudden threat or loss to the } \\
\text { whole organization }\end{array}$ & $\begin{array}{l}\text { Defensive response with } \\
\text { reliance on the known and } \\
\text { trusted }\end{array}$ \\
\hline $\begin{array}{l}\text { The 'Python' type of crisis } \\
\text { gradually creeps upon a } \\
\text { company, for example, } \\
\text { caused by poor management } \\
\text { or high costs. }\end{array}$ & $\begin{array}{l}\text { Bureaucratic response when } \\
\text { the crisis is not recognized- } \\
\text { negotiated response when } \\
\text { crisis recognized }\end{array}$ & $\begin{array}{l}\text { Periodic threat or loss to part } \\
\text { or whole of the organization } \\
\text { Gradual threat to part of the } \\
\text { organization }\end{array}$ & $\begin{array}{l}\text { Negotiated response and } \\
\text { recognition of the problem } \\
\text { crisis is not recognized }\end{array}$ \\
\hline
\end{tabular}


According to Table 2, 9/11 is a Cobra crisis because the terrorist attacks were sudden and surprising. People, businesses, and the government were unprepared. This is the biggest difference between 9/11 and COVID-19. COVID-19 is a Python crisis. The first known case of COVID-19 can be traced back to November 2019. It was declared a pandemic in the United States on March 11, 2020. This shows the slow, gradual onset of the crisis. Because of this, there are monumental, long-term effects that perhaps the nation did not see as a result of $9 / 11$.

\begin{tabular}{|c|c|c|}
\hline Model & Approach & Limitations \\
\hline Caplan's (1970) crisis model & $\begin{array}{l}\text { Psychological perspective, whereby the } \\
\text { focus is on how the individual copes } \\
\text { with a crisis }\end{array}$ & $\begin{array}{l}\text { The model lacks precision and is } \\
\text { descriptive. The most important } \\
\text { criticism is that it is homeostatic }\end{array}$ \\
\hline $\begin{array}{l}\text { Slatter's (1984) crisis susceptibility } \\
\text { model }\end{array}$ & Economic approach to crises & $\begin{array}{l}\text { It suggests only the factors that are } \\
\text { susceptible to a crisis in an organization. } \\
\text { It is not a process, merely a model } \\
\text { stating factors that may cause a crisis }\end{array}$ \\
\hline Arnold's (1980) model of crisis & $\begin{array}{l}\text { Sociological perspective and looks at } \\
\text { how communities react to crisis }\end{array}$ & $\begin{array}{l}\text { Only focuses on the sociological view } \\
\text { and centers on the individual in relation } \\
\text { to a group. The way an individual views } \\
\text { the crisis may be different to the } \\
\text { organization }\end{array}$ \\
\hline $\begin{array}{l}\text { Process model of crisis development } \\
\text { (Booth, 1993) }\end{array}$ & $\begin{array}{l}\text { Aims to identify features that appear to } \\
\text { be common in many crises }\end{array}$ & $\begin{array}{l}\text { Too general and simple - all crises are } \\
\text { unique in terms of the particular causes } \\
\text { and effects involved }\end{array}$ \\
\hline $\begin{array}{l}\text { The crisis life cycle (Seymour and } \\
\text { Moore, 2000) }\end{array}$ & $\begin{array}{l}\text { Looks at the obstacles to decision } \\
\text { making during a crisis }\end{array}$ & $\begin{array}{l}\text { Too descriptive and general - although } \\
\text { can be made to fit any organization }\end{array}$ \\
\hline Clarke and Varma (2004) & $\begin{array}{l}\text { Presents a model of risk management as } \\
\text { a strategic process }\end{array}$ & Difficult to put into operation \\
\hline $\begin{array}{l}\text { Model of crisis management (Smith, } \\
\text { 1990; Smith and Sipika, 1993) }\end{array}$ & A process from start to finish of a crisis & May be too general and descriptive \\
\hline
\end{tabular}

Table 3. Crisis Management Models, Approach, and Limitations. ${ }^{1}$

Evans \& Elphick then go on to explain crisis models that have been executed, as well as their approaches and limitations (see Table 3). Arguably, 9/11 followed Caplan's (1970) model: "Psychological perspective, whereby the focus is on how the individual copes with a crisis." Many aspects of the nation were affected after 9/11; arguably, the biggest effect was air travel and security changes. With TSA policies in place, the government was focused on how to calm people's nerves, fears, and anxieties about the safety of their country and their aircraft.

At the time of this writing, the COVID-19 pandemic was still in the first wave regarding the travel industry. The same model will likely be applied. People were fearful of traveling out of their houses, let alone across the world. When the time comes that widespread travel is allowed, the travel industry will need to have a crisis model prepared. While the government will most likely place restrictions on travel and new policies, it is up to the travel industries and each firm to instill confidence and safety to the individual. Evans \& Elphick outline the limitations of Caplan's crisis model, stating: "the model lacks precision and is descriptive. The most important criticism is that it is homeostatic." Once the world is fully running again, the travel industry must be quick on its feet to adjust to the consumer emotion. They cannot merely put policies in place, such as with $9 / 11$; they must constantly be responding to the evolving consumer response.

After 9/11, internal communication was a top priority. Argenti (2019) wrote an article for the Harvard Business Review in which he worked with managers to understand the crisis response, specifically to $9 / 11$. He states initially: "What I discovered is that, in a 
time of extreme crisis, internal communications take precedence. Before any other constructive action can take place-whether it is serving customers or reassuring investors - the morale of employees must be rebuilt". ${ }^{14}$ This firmly held true regarding the COVID-19 crisis. Internal communication was, and is, key. Hospitals sent out new policies and updates every few days to their employees. Before the stay-at-home order, employees were being informed of every change that was taking place.

Argenti then continues to lay out a five-step process for a company facing post-crisis:

Get on the scene. The most important thing after a crisis is to jump onto the scene immediately. This can mean press conferences or statements. It is important to stay visible to the customer. Concerning $9 / 11$, there were many press conferences and speeches made all over the nation in the days following. "'When people heard us on the speakers, they listened. Your voice must sound calm, in control and, most important, earnest,' says Lewis, thinking back...' most of all, we wanted people to know we were all in the same boat'". 14

This concept remains true for COVID-19. Many companies and firms released statements on their positioning or availability of service due to the pandemic. Everyone heard from their bank, their doctor, the drug store, even retail stores. Companies that were still offering services kept extremely high visibility. Printing signs that read "OPEN FOR DELIVERY," among other postings.

Choose your channels carefully. "Whether natural or man-made, disasters often disrupt normal flows of communication."14 For 9/11, one of the internet companies crashed, and cell towers were down, which had a huge effect on lines of communication within New York. " $[\mathrm{M}]$ any of them realized that they needed to start thinking of the media as allies-in part because their failed communications systems left them no other choice". ${ }^{14}$

For COVID-19, digital and media communications were the only flows of communication. There were live streams daily from government officials and doctors. Churches were live streaming services. People were stuck in their homes, and they were bored. They were turning to digital communication for information, statements, and entertainment. Many companies decided to release and stream fun challenges, ads, or memes to keep the consumer's attention.

Stay focused on the business. During 9/11, it proved effective to have people focus on work. People felt lost and unsure, and so having "an outlet for their desire to help, gets them back into a normal routine, fosters their pride in the company and what they do, and builds strong bonds between themselves and their customers, many of whom desperately need the company to keep their products and services flowing". ${ }^{14}$ By having somewhere to place their energy, people felt not only productive, but also felt helpful and beneficial to the greater cause.

In the first wave of COVID-19, many people were out of work or working from home. This has had a large effect on the economy, and it also has a huge effect on morale. Companies began to find creative ways for people to feel productive and beneficial. There were challenges to complete that raised awareness. Companies were selling specific new product lines with proceeds going to COVID-19 relief. Even celebrities were auctioning off events to raise donations. This brought aid to those in need, but it helped them stay focused on business and the greater good on the consumer side.

Have a plan in place. Argenti urges strongly for the use of web-based communication and for contingency planning. Even with intranet servers down, there needed to be strong communication. "Although operations during a crisis should be decentralized, decision making should not be." Decision-making must continue to be strong and centralized amongst the chaos.

COVID-19 has proved this idea many times over. All nonessential firms decentralized operations and offices, but the company's decision-making and forward motion needed to continue. This is why so many people could continue to work from home.

Improvise but from a strong foundation. "CEO John Murphy says, 'If you have a strong culture, you can maintain focus. On 9/11, we had a structure, a belief system, and a hierarchy all in place. That helped us to get through the crisis, and we have not skipped a beat since'". ${ }^{14}$ Because of the strong foundation, after 9/11, firms were able to move forward and show the consumer the future through the eyes of their belief system.

During COVID-19, firms acted very quickly. For example, a medical device company, Stryker, was able to push out an emergency bed in 10 days from original conception to when the bed was in the hospitals. Many companies, specifically 
insurance, travel, and cell, had advertising out that amplified their belief in bringing people closer together during this time. These industries believe in community power; during this time of social distancing, they released ads that created emotions of togetherness and familiarity. They told the consumer that "we want to bring you together virtually and keep you safe right now."

\section{Effect on the Travel Industry}

Being as the major vehicle in the terrorist attacks of 2001 were airplanes, the travel industry took a huge economic hit afterward. Right after the attacks, all commercial flights were grounded for three days. This "resulted in a 31.6 percent reduction in travel volume in September of 2001 compared to that same month in 2000 and generated massive industry losses". ${ }^{15}$ People were afraid to fly but were still willing to travel. Due to COVID-19, most commercial flights were canceled during the stay-at-home order, and we do not yet know the complete economic effect this will have. The biggest difference during COVID-19 is that people are afraid to travel, not just to fly. People are afraid to go anywhere, and this will cause major impacts on the lodge industry, tourism industry, restaurant industry, tour operators, and the airline industry. These all combine to create a broader impact on the travel industry.

\section{DISCUSSION}

\section{Consumer Emotional Response}

The initial consumer response to $9 / 11$ was intense. People were scared and shocked. People were confused by what had happened; it was sudden and unexpected. People were anxious and fearful of what the future, as well as the present, held. Many questions were unanswered. This, of course, led to people being fearful of flying. Even a year after the attacks, the consumer response was the same. "U.S. consumers are now more wary of foreign travel, with $39 \%$ saying they are less likely to travel abroad, according to Euro RSCG Worldwide's Mind and Mood Monitor. They regard 'home as a haven"'. ${ }^{16}$ The phrase "home as a haven" is very powerful. Consumers turned to the emotional pull of "we are American." There was great pride in how the country bound together and linked arms to be one nation, one home. This is not something that happens very often in the United States. There must be a strong enough emotional response. This nationalism and patriotism ran through homes, stores, and the government. As this wave was felt, " $50 \%$ of people aged over 50 say they are now more likely to 'buy American"'.16

The initial consumer response to COVID-19 was a lot slower because the crisis was a Python crisis. The emotional response was annoyance that changed into fear and anxiety, fear for the world's unknown state and the nation for both the present and the future. The first response to airlines and travel was to buy as many good deals as possible; however, when the reality of the situation settled in, people were ready to travel but scared of the actual act and the consequences. "Home is haven" quite literally during stay-at-home state orders. While people may not have been emotionally content with this, they were fighting for everyone who could not stay home. There is a nationwide awareness that every individual's role is to play the part for the greater good and create a national haven and safe space. There is a rise in patriotism, a patriotism that is different from before; it is not Americans against terrorists but Americans against an untouchable disease. This is not to say it is better or worse, just that it feels different because every American has directly felt the effects of this pandemic. "America has long equated patriotism with the armed forces. However, you cannot shoot a virus. Those on the frontlines against coronavirus are not conscripts, mercenaries, or enlisted men; they are our doctors, nurses, pharmacists, teachers, caregivers, store clerks, utility workers, small-business owners, and employees. When all is said and done, perhaps we will recognize their sacrifice as true patriotism, saluting our doctors and nurses, genuflecting". ${ }^{17}$

"Shop Local" has been a very important phrase in the media right now. This parallel to "buy American" is not lost. People want to support their neighbors, near and far. The fact that this is happening amid the pandemic only predicts that it will continue forward as life adjusts back to normal. When people feel safe enough to travel, they will travel for one reason to support communities and local businesses. People will want to experience culture and art through the "underdog." "Localism is likely to be a much stronger factor, particularly in the early stages of recovery. Not only will this assist with social reconnection, it is [sic] a more sustainable model that supports climate change adaption [sic]". ${ }^{18}$

\section{Market Response}

Budget response. One of the biggest responses to 9/11 within the market was asking, "why do we spend money on advertising?" With the change in dynamics and media, there were big discussions about where and what advertising money was being spent:

Budget Cuts. The increased reliance on public relations may be attributed to the need to reduce budgets for advertising and marketing, which traditionally use strategies and tactics that are more expensive than public relations, rather than 
public relations' expertise regarding persuasive appeals and message structure. One major reason for the budget shift appears to be less bed tax revenue due to low hotel occupancy. ${ }^{19}$

This question of advertising goes into evaluating where the most effective use of money will be to be able to draw people back into the market after a crisis. "We shifted our budget greatly to funnel more funds into advertising and public relations that would convince a "scared" public that travel is safe and appropriate". ${ }^{19}$ Advertising budgets have already shifted because of COVID-19 while firms decide how consumers will respond.

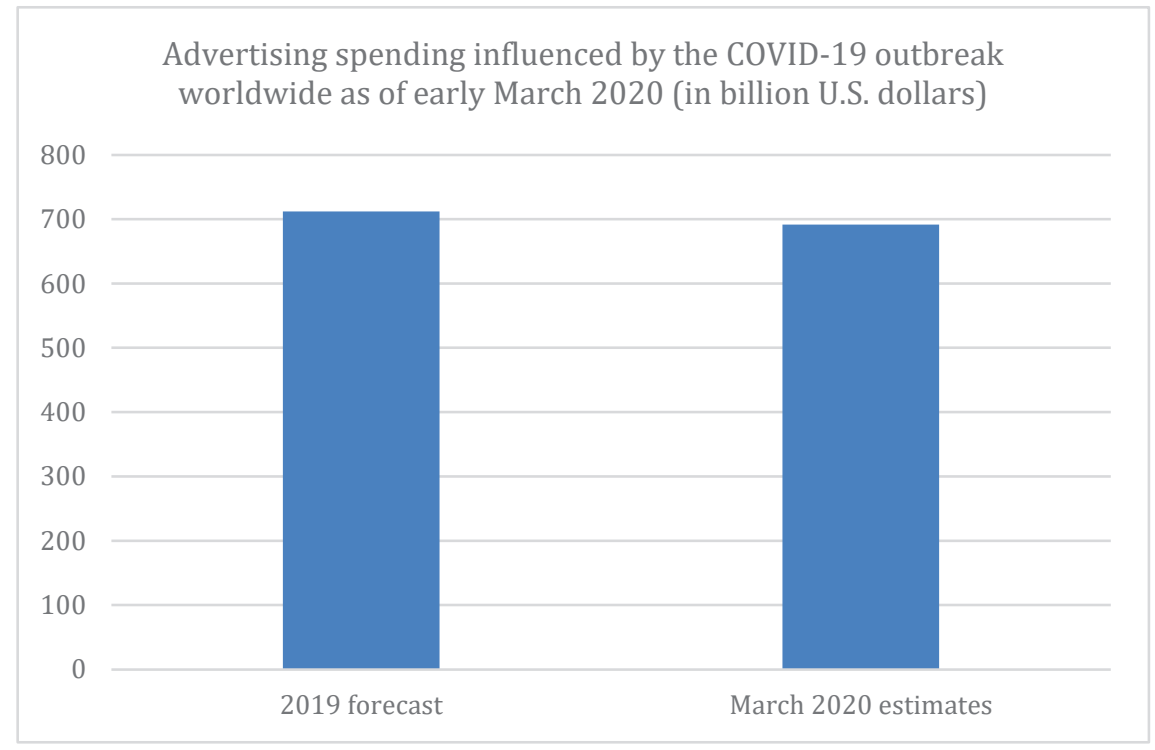

Figure 1. Advertising Spending Influenced by COVID-19 as of early March $2020^{20}$

Pre-epidemic March 2020

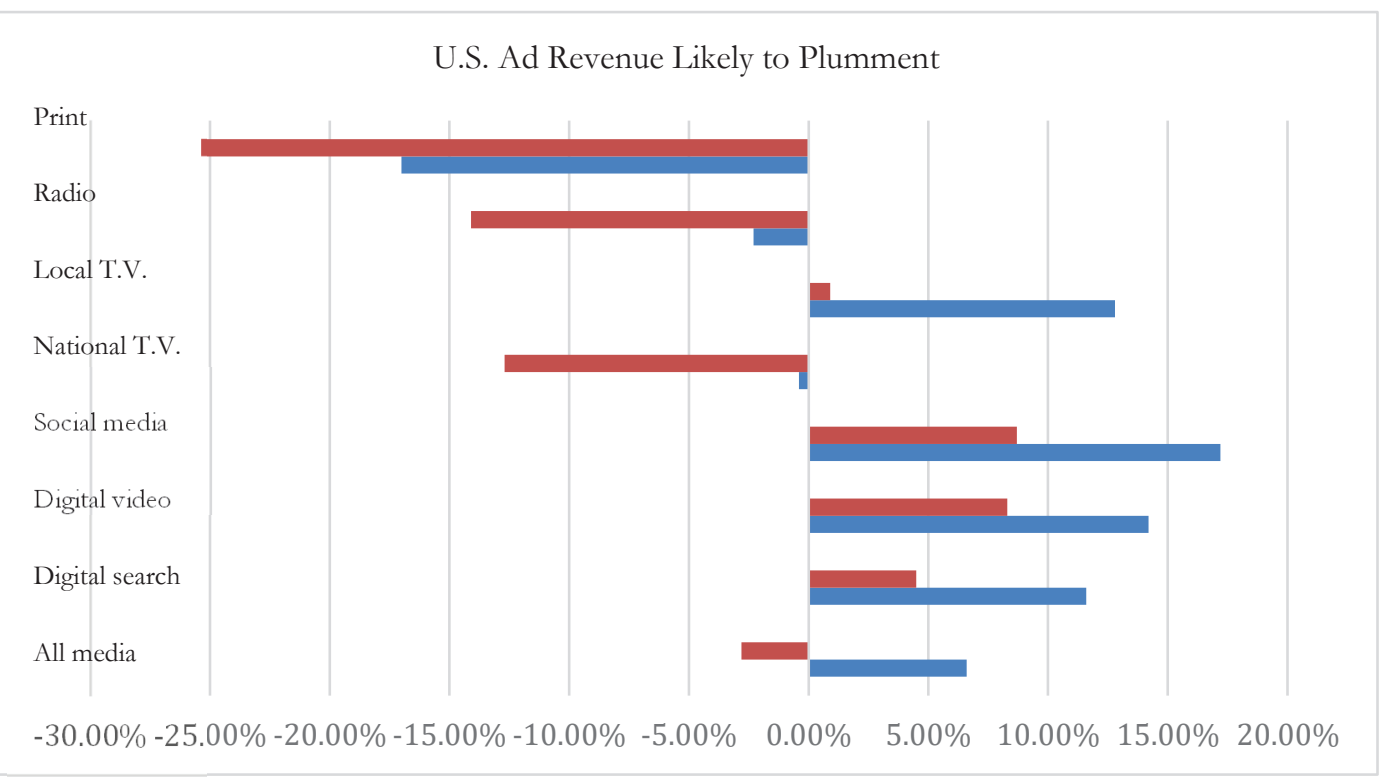

Figure 2. U.S. Ad Revenue Likely to Plummet Pre-epidemic vs. March 202021

Geographical travel response. Another big market response to 9/11 was that everyone was driving and traveling closer to home. "According to a Travel Industry Association of America (TIA) report on changing travel patterns, three-fourths of its members are seeing an increase in closer-to-home travel and last-minute travel among their customers". ${ }^{19}$ Everyone transitioned to close to home adventures. When it came to travel, people were concerned with the destination and the emotions related to it, and so they would sacrifice, no matter how far, in order to be in tune with those emotions. "[D]estination image should incorporate both cognitive (beliefs and knowledge about a travel destination's attributes) and affective facets (emotion or feelings attached to the 
destination)... destination image is a significant mediator between perceived travel risks and visit intention". 18 The important objective was to draw close together as a nation. The only way people were traveling was if the emotional pull outweighed the travel risk.

We can predict that the same situation will happen with travel after COVID-19. Consumers that do travel will need a high emotional pull to that specific destination. Anyone who travels by plane, to be in tight quarters with strangers for hours, will need to have an even greater emotional drive to overthrow the fear.

Travel Advertising and Messaging After Crisis

Advertising Strategies After $9 / 11$

Promotional push instead of pull strategy. Because of emotions of fear, anxiety, and anger, it was very effective to use push marketing and advertising to push people into travel. "[W] hile pull factors refer to those that lead an individual to select one destination over another once the decision to travel has been made. Push factors are viewed as relating to the needs and wants of the traveler... Pull factors, on the other hand, have been characterized in terms of the features, attractions, or attributes of the destination itself... (p. 385)". ${ }^{19}$ These push factors must be strong enough to once again overcome the travel fears. The advertiser needed to push the traveler past the psychological aftermath. Companies quickly ran campaigns, not only to get their message out immediately but also because "there [was] an unspoken awareness that another September 11—God forbid—could cause more lasting damage. There's a slight sense of urgency, of making hay while the sun shines". ${ }^{22}$

For the tourist traveler. For the travel industry, they also needed to run push campaigns. The travel and tourism industry normally focuses on pull factors: drawing the consumer in with events and mass media. This is not effective during moments of high emotion, tension, or crisis. For the travel industry as a majority, most of them could successfully advertise to consumers if they could avoid airlines. "As a result, $87 \%$ of its member organizations have changed their marketing or promotion programs, with $77 \%$ focusing their efforts on closer, drive-in markets during the last 12 months (Keefe, 2002a)". ${ }^{19}$ However, the airlines had to push even harder to try and compensate for the emotional toll.

The travel industry needed to focus on the push or emotional effect of entertainment in each destination:

'People want to get back to what is real. I plan to not focus on entertainment as much as the way people feel while they are in Dickson County.' Human interest and "feel good" stories also are being used by a major tourist attraction in the Southeast, and an attraction in the West reported that it is 'using more visual imagery-our animals, bright colors, happy people-to better relay [a] sense of fun and wonder.'19

For tourism in general, there needed to be a sense of normalcy and a heightened normalcy-fun. People needed a break and release from the emotional strains of the attacks:

The key to activating local visitor economies will be to increase demand, but (even assuming this would work with the entire world competing for scarce tourism spend) intensive marketing to attract large numbers of visitors may overwhelm the limited resources and capacity of the remaining businesses. Instead, the initial focus should be on visitor segments that can function happily within the constrained environment, spending money in the grassroots businesses (cafes, shops, wineries) that underpin the tourism sector. Similarly, after the total closure of music venues (with many not expected to re-open if travel/social restrictions extend for several months), new venues for live music and entertainment will be needed, presenting opportunities for co-creation of cultural experiences in wineries, cafes, galleries and local pubs. ${ }^{18}$

The travel industry also needed to focus on a destination's localism, such themes discussed earlier as in "the Dream American" and "home as in haven." The industry gave space for the consumer to see and support the local tourism, businesses, and economies of each destination. Furthermore, the advertising needed to create a sense of community.

For the corporate traveler. Messaging and strategy for the corporate traveler are slightly different; however, focusing on the corporate traveler may be what keeps a company from going under. In many cases, this travel is vital, and so the competition for that consumer is high. The corporate traveler will be pushed with promotions and deals, so a company must rise on time with a promise of improved safety and service. The importance is to figure out exactly what those improvements look like. "[T]he ability of the travel service provider to contribute to effective business outcomes and the safety of the traveler". ${ }^{21}$ 
Messaging After 9/11

Through looking at the consumer's emotional response to $9 / 11$, some of the main messaging has already become clear: home as in haven, buy American, and patriotism.

American Dream. The first messaging is the American Dream and patriotism. Even restaurants were using this messaging to push consumers to go out to eat. '[T] he 'I Love New York' and other marketing campaigns'... 'We have several hundred events scheduled this year, everything from festivals to performing arts, stage plays, and the new film center in Pleasantville. We hope these will attract even more visitors this year"', 23

G.M. advertising introduced us to this concept, as they were one of the first to carry this messaging. They drew on the American Dream and ended up breaking auto sale records in October 2001.19 "G.M. acted forcefully with a marketing campaign and financial incentives at the time when many marketers were tentative and uncertain". 3

Figure 3 GM Advertisement ${ }^{24}$

https://www.marketplace.org/2020/04/03/advertisers-aretrying-adapt-covid19/

Confidence in safety. The next messaging was to instill confidence and inform the consumer about the changes and safety precautions in place-precautions that would push past the emotional trauma. Tampa International Airport was able to implement this with the American Dream. They ran a campaign with the slogan "'Keep Flying America' that was implemented to educate the public about changes in airline travel since $9 / 11$ and to help relieve the fear of flying". ${ }^{25}$

American Airlines, one of the airlines used in the attacks, ran two campaigns. ${ }^{25}$ The first campaign was a commercial that, over a minute, read "We are an airline. But it has become clear we are more. We are a way of life. The freedom to come and go, anywhere, anytime, with confidence and peace of mind. We are an airline that is proud to bear the name: American." They pushed forward with pride in their company and their nation. They also conveyed the importance of feeling confident and peaceful about your travel.

We are in this together. The final messaging is that we are all in this together. American Airlines' second campaign consisted of three commercials with the slogan "The Great American Get-Together. Be a part of it," with discounts for in-country flights. Each video boasted its own theme, respectively: family, friends, and getaway. Each video talks about people that are "somewhere in America." The family video named different individuals and activities like a camera-shy mom and muddy backyards that will become football fields. The friends' video shows the breadth of a lifelong friendship from young children to old friends: "You knew you'd be back, you'd all be back together. Somewhere in America." The getaway video talks about how somewhere there is a lack of errands, homework, but time, memories, and journeys are bound to be brought together. "Somewhere in America...the best way to get together is simply to get away."

United Airlines ran a campaign: We are United. Different employees talked about why they do what they do and how they are here for us. "We took a blow... but we are going to get up, and stand up, and press on."

Market Response and Advertising Already in Place for COVID-19

Because COVID-19 is still currently a crisis worldwide as of November 2020, there must already be advertising in place.

Reviewing this starts with the market response statistically, and then the messaging already in use.

Statistics

Focus and uses of media have shifted. Consumers were bored and at home with nothing to do. See Figure 4 to watch the rise of on-demand media as people searched for mindless ways to occupy their time. Figure $\mathbf{5}$ showcases how specifically the older population was filling their time with news channels. People were scared and over researching the virus and were hyper-aware of the news.

\section{Messaging}

Stay At Home. Main messaging circulates themes regarding the stay-at-home order. Companies were trying to stay visible in front of consumers. Big companies were taking the responsibility of pushing people into their homes. Through this, they were staying at the front of the mind for the consumers. WhatsApp had a commercial that even celebrates the togetherness that is possible during social distancing: "In the Distance, Stay Close." Coca Cola (Figure 6) encouraged people that by staying apart, they are uniting the human race. Nike had a similar play off of this theme by showing that staying inside unites humanity as one team or audience (Figure 7). Toyota had parallel messaging as the following Honda ad (Figure 8). Toyota had a South Africa commercial running that shares how much they love to get people moving but being home has never felt so right: "We Look Forward to Everyone Being Back on the Road." McDonald's (Figure 9) does not have any direct underlying themes but encourages 
separation by altering their logo. Finally, Spotify (Figure 10) encouraged social distancing by offering music to relieve the stress and loneliness of COVID-19.

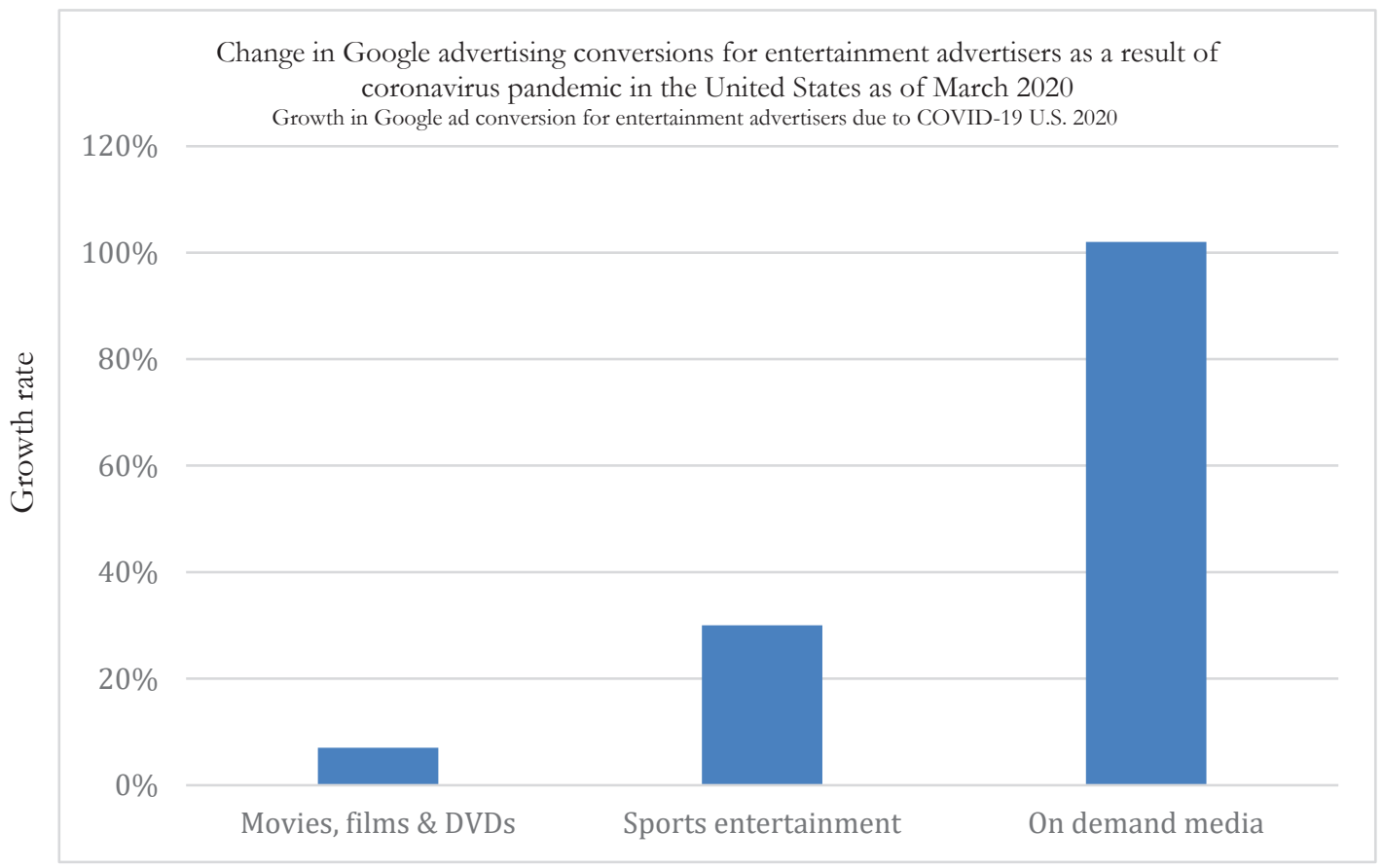

Figure 4. Change in Google Advertising as a Result of COVID-1926

Aged 25-54

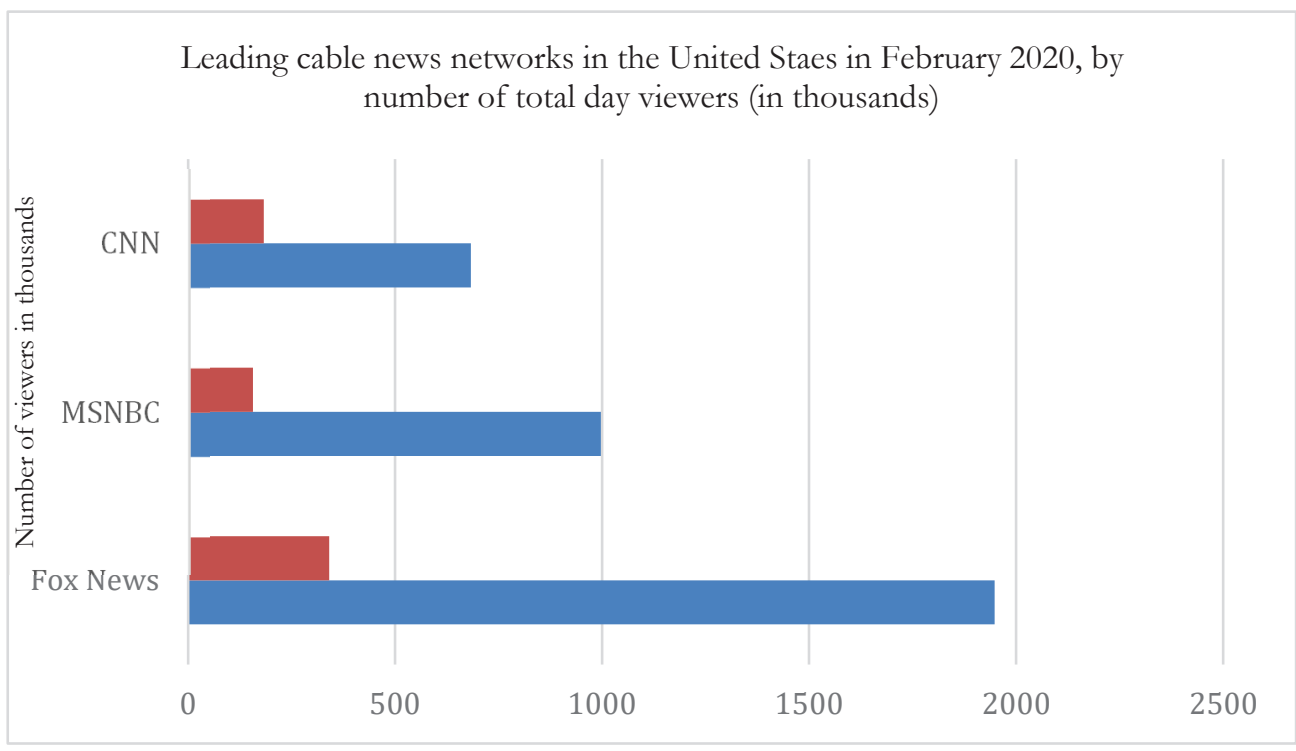

Figure 5. Leading Cable News Networks as of February 202027

Figure 6. Coke $\mathrm{Ad}^{28}$

Figure 7. Nike $\mathrm{Ad}^{29}$ https://www.campaignlive.com/article/coke-goes-big-covidsocial-distancing-times-square/1677909

https://www.gartner.com/en/marketing/insights/dailyinsights/how-active-are-activewear-brands-in-the-fightagainst-covid-19 


\begin{tabular}{|l|l|}
\hline Figure 8. Honda Ad ${ }^{30}$ & $\begin{array}{l}\text { https://auto.hindustantimes.com/auto/news/stay-home- } \\
\text { honda-promotes-covid-19-awareness-with-this-homemade- } \\
\text { civic-commercial-41587186158063.html }\end{array}$ \\
\hline Figure 9. McDonald's Ad ${ }^{31}$ & $\begin{array}{l}\text { https://www.today.com/food/mcdonald-s-changes-golden- } \\
\text { arches-logo-amid-coronavirus-outbreak-t176653 }\end{array}$ \\
\hline Figure 10. Spotify Ad ${ }^{32}$ & $\begin{array}{l}\text { https://techcrunch.com/2020/03/25/spotify-adds- } \\
\text { fundraising-features-and-a-covid-19-news-hub-to-address-the- } \\
\text { health-crisis/?guccounter=1 }\end{array}$ \\
\hline
\end{tabular}

We are in this together. The biggest messaging theme is we are in this together. Once again, we see the parallelism of bringing people together and patriotism rising to draw together our strength. Companies are pushing that they are here with the consumer. They are walking alongside them, and they will be there through every step. Through this, they show they will be there for the steps afterward. Ford led the way on this messaging with a commercial that named everyone affected, followed by a link for support from Ford. Then the screen read "Built for America." This is patriotism and huge togetherness. Jack Daniels had a commercial running that reads "Dear Humanity, Here's to social distancing, socially. Love, Jack." This, in so many words, is telling the consumer that Jack Daniels is here with them. Many other companies also chose to use this branding. Even the government has participated. The State of Ohio had a campaign running for \#inthistogetherohio, where famous figures around the state share that they are here for everyone.

Travel airlines have taken this concept even a step further. Not only do they show the consumer that we are in this together, but most of them are sharing their purpose behind the industry: you. American Airlines has extended its elite status program for an extra year because you are important. They have a commercial running with the campaign slogan, "You are why we fly." The video shows what American Airlines is doing to transport health professionals and medical supplies to keep you safe. Visually, it strongly parallels the campaign American Airlines from 9/11. Delta is running a campaign slogan "Our Promise: Your Safety Above All" and "Together as One." Delta is stating both messaging in their social media; they are also showing how they are transporting supplies.

\section{COVID-19 Post-Crisis Advertising Predictions}

Advertising Strategies

The major advertising strategies after COVID-19, specifically within travel, will largely mirror those of 9/11.

Promotion push instead of pull strategy. Although an unmeasurable bet, it is safe that emotions are higher right now than they have ever been as a collective nation. People are feeling all sorts of emotions in a combination that has not been felt before. There is fear for both the present and the future. There is fear over household finances. Greatest of all, there is fear and anxiety for the health and safety of oneself and one's families. Travel companies and destinations need to push the consumer and the traveler through their needs and wants. The advertiser needs to push the traveler past the psychological aftermath.

For the tourist traveler. To push the tourist to a new destination, advertisers will focus on the feelings that come with entertainment and localism. People are bored and unsettled. The population has been living in a state of temporary normal, and they will "want to get back to what is real." 19 The entertainment, the carefreeness, and the fun of travel will immediately appeal to them. We can expect to see new events, festivals, and "coffee shop passports" popping up. They needed a sense of community. A community that "demonstrates that visitors would be welcome, and serve as a guide to enjoying the available tourism product in that locality."18 This "meet[s] the social connectivity imperative and help[s] to build demand for local services that will in turn support supply-side development."18

For the corporate traveler. The corporate traveler advertising strategy will need to focus mainly on instilling confidence, safety, and customer satisfaction into the consumer. If they must travel, then each airline and hotel needs to differentiate themselves from the competition. Corporate travel will need to continue at some point, so it is up to each company's marketing teams to distinguish themselves. The corporate traveler will be looking for outstanding customer service and safety. They will also be looking to be persuaded of the need to travel over video conferencing. Advertising will have to showcase the distinct value to in-person business.

\section{Messaging}

Below are the six main advertisement messaging constructs that are predicted to come from COVID-19, specifically within the travel industry: 
American Dream. Messaging of the American Dream will come from both destinations and from travel companies. This will come in multiple forms. There will be new festivals, concerts, events, and challenges that boast of patriotism and city pride. There will be ads, specifically in airlines, which push the need to keep supporting America and using American companies to travel. There will be messaging and feelings of community and togetherness because "we," as America, got through it.

Confidence in safety. For airlines specifically, there will be many campaigns run around the concept that they have instituted more safety procedures and precautions. This has already been initiated. As seen above, many companies are pushing safety as the top priority and featuring masks in every image and video. Airlines will need to overcome the consumer fear and show that they will take care of them and that they will make sure safety in travel is their number one priority. We are in this together. This one will also strongly mirror 9/11 ads. If American Airlines used the exact same wording in a new commercial: "You knew you would be back, you'd all be back together. Somewhere in America." Would anyone be surprised? Verbiage and emotions are the same. These companies want the consumer to know that they are here to help and make everything as smooth and easy as possible. However, they also want to show the consumer that their priority lies within the individual's emotions and well-being.

Support local tourism. This has already become a theme among the nation during COVID-19 but will be vital to put into place regarding travel. People want to feel that they are welcome wherever; that they do not have to only stay in their space. The local community needs to be welcoming and to make people feel like their connectivity is desired. This will increase the demand for local businesses. People will want the chance to support local businesses and financially by experiencing their goods and services.

Connect with those you missed. The biggest emotional pull that will override the travel fear will connect with the people you missed. Much like the campaign from American Airlines after 9/11, there will be ploys to connect with family, friends, and nature. There will be narratives about the time wasted and the need that you have to connect. There will be information about the human need for connection.

Explore your city in a new way. Even though travel is normally thought of as adventure and abnormal, in contrast to the stay-at-home order, it will feel so exciting and desired that consumers will believe travel and freedom was always a part of what was real to them. The advertiser will need to push that emotion of fun enough so that the consumer can overcome the emotional fear of traveling and contracting COVID-19. For tourism in general, there needs to be a sense of normalcy and heightened normalcy or fun. People need a break and release from the emotional strains of the pandemic. There will be an increase in opportunity and demand. This is where tourism companies need to step in to create events, themes, and situations where the tourist can feel free and safe.

\section{Qualification}

COVID-19 is, in one sense, completely different from the attacks on 9/11. Economically the effects are already much larger:

Recent pandemics had markedly different infection patterns compared to COVID-19. Hence financial losses were comparatively low. In 2008, the World Bank predicted that the global cost of a bird-flu pandemic would be $3.1 \%$ of World GDP, which in 2019 was $\$ 88,081 \mathrm{~b}$ - resulting in an estimated 2019 cost of $\$ 2,732 \mathrm{~b}$. COVID-19 will generate a much more significant disruption than the World Bank's 2008 prediction, with the World Economic Forum (in March 2020) estimating that the cost of COVID-19 in 2020 will be at least US $\$ 1$ t.. ${ }^{1}$

However, because of the state of crisis and emotional similarities, as a marketer, we can take $9 / 11$ as a mere shadow of what will happen after COVID-19. 9/11 unified the United States, while in many ways, COVID-19 divided the nation.

\section{CONCLUSION}

The United States and the world have been through many crises over recent decades. There have been health pandemics, including SARS, H1N1, and Ebola outbreaks. There have been security crises like 9/11. In 2020, there was COVID-19. In these crises, the nation pulls together to support the American people and the American economy. For COVID-19, when life begins to emulate "normal," advertising will look a lot like it did after 9/11. There will be a push for consumers to reach over their emotional fears. There will be messaging to draw in consumers to the American dream, local tourism, see the world in new ways, and reconnect to their roots. 


\section{ACKNOWLEDGEMENTS}

Hannah thanks Dr. Allen Knight for being a constant encouragement in her academic success and for pushing her to be better, Dr. Caleb Chan for leading in a way that shows how to make Christ evident in a business career, her dad and family for encouraging her always to strive higher professionally, her mom for pushing her to consider COVID-19 as a research topic, Katie Warner for reading through every draft, and finally, her college roommate, Samantha Marchand, for listening to every new thesis idea before settling on this one.

\section{REFERENCES}

1. Evans, N., \& Elphick, S. (2005) Models of crisis management: an evaluation of their value for strategic planning in the international travel industry. International Journal of Tourism Research, 7(3), 135-150. doi: 10.1002/jtr.527

2. JeffCoxCNBCcom. (2020, July 30). Second-quarter GDP plunged by worst-ever 32.9\% amid virus-induced shutdown. Retrieved from https://www.cnbc.com/2020/07/30/us-gdp-q2-2020-first-reading.html (accessed October 2020)

3. Johnson, B. (2020, March 17) Opinion: What $9 / 11$ can teach us about marketing in the time of coronavirus. Retrieved from https:// adage.com/article/ cmo-strategy/opinion-what-911-can-teach-us-about-marketing-time-coronavirus/2244906 (accessed Mar 2020)

4. Microsoft: The Power of Teams. (2020, April 01). Retrieved from https:/ / www.adsoftheworld.com/ media/film/ microsoft_the_power_of_teams? className=collection-lb (accessed October 2020)

5. Mike Axisa \&. R.J. Anderson. (2020, September 15). MLB schedule has 43 total games postponed due to positive COVID19 cases. Retrieved from https:// wmw.cbssports.com/mlb/news/mlb-schedule-has-43-total-games-postponed-due-to-positive-covid-19-cases/ (accessed October 2020)

6. Pond, S. (2020, April 06). All the Awards Shows That Have Been Canceled, Postponed or Made Rule Changes Because of Coronavirus. Retrieved from https:/ / www.thewrap.com/ all-the-awards-shows-that-have-been-canceled-postponed-or-made-rule-changesbecause-of-coronavirus/ (accessed October 2020)

7. Brown, M. (2020, May 01). An Inside Look At The NFL's 2020 Virtual Draft Shows Elements Are Here To Stay. Retrieved from https:/ / www forbes.com/sites/maurybrown/2020/05/01/an-inside-look-at-the-nfls-2020-virtual-draft-shows-elements-are-here-to-stay/ (accessed October 2020)

8. Vary, A. (2020, August 06). With 'Mulan,' Disney Tests Out Entirely New Early VOD Model. Retrieved https:/ / variety.com/2020/film/news/mulan-disney-plus-premiere-1234711185/ (accessed October 2020)

9. Salcedo, A., Yar, S., \& Cherelus, G. (2020, March 15). Coronavirus Travel Restrictions, Across the Globe. Retrieved from https:/ / www.nytimes.com/ article/ coronavirus-travel-restrictions.html (accessed October 2020)

10. Prast, R. (2020, September 10). Update: Many 2020 Las Vegas conventions move to 2021, go virtual. from https:/ / wmw.reviewjournal.com/ business/conventions/ update-many-2020-las-vegas-conventions-move-to-2021-go-virtual-1989650/ (accessed October 2020)

11. Redaktion, O. (2020, April 21). Oktoberfest 2020 is cancelled: "It hurts!" Retrieved from https:/ / wmw.oktoberfest.de/ en/magazine/oktoberfest-news/2020/oktoberfest-2020-will-be-cancelled (accessed October 2020)

12. Coronavirus: Irish St Patrick's Day parades cancelled. (2020, March 09). Retrieved from bttps:// www.bbc.com/ news/world-europe51806551 (accessed October 2020

13. Perez, S. (2020, March 30). Videoconferencing apps saw a record 62M downloads during one week in March. Retrieved from https:// techcrunch.com/2020/03/30/video-conferencing-apps-saw-a-record-62m-downloads-during-one-week-in-march/ (accessed October 2020)

14. Argenti, P. A. (2019, January 04) Crisis Communication: Lessons from 9/11. Retrieved from https:// hbr.org/2002/12/crisiscommunication-lessons-from-911 (accessed Mar 2020)

15. Clark D.E., McGibany J.M., Myers A. (2009) The Effects of $9 / 11$ on the Airline Travel Industry. In: Morgan M.J. (eds.) The Impact of 9/11 on Business and Economics. The Day that Changed Everything?. Palgrave Macmillan, New York.

16. Dignam, C. (2013, July 23) Marketing After 9/11. Retrieved from bttps:// wnw.campaignlive.com/article/marketing-9-11/158038 (accessed Mar 2020)

17. Magazine, P. (2020, April 15). Coronavirus Will Change the World Permanently. Here's How. Retrieved from https://www.politico.com/news/magazine/2020/03/19/coronavirus-effect-economy-life-society-analysis-covid-13557 (accessed October 2020)

18. Peters, K., Peters, J., \& Peters, N. (2020) Visit People Tourism Recovery After Disaster. KPPM Strategy, 1-17.

19. Carden, A. R. (2005) The Use of Persuasive Appeals and Public Relations in the Travel and Tourism Industry Post-9/11. Journal of Hospitality \& Leisure Marketing, 12(1-2), 79-95. doi: 10.1300/j150v12n01_06

20. How COVID-19 Has-And Has Not-Affected Global Ad Spending. (n.d.) [Digital image]. Retrieved from https:// www.emarketer.com/ content/ how-coronavirus-affects-global-ad-spending (accessed Mar 2020)

21. Roper, W. (March 27, 2020) U.S. Ad Revenue Likely to Plummet [Digital image]. Retrieved May 09, 2020, from https:/ / www.statista.com/ chart/21271/ad-revenue-forecasts-after-coronavirus/ (accessed Mar 2020)

22. Gautier, A. (2002, April) The Business of Travel. N.Z. Marketing Magazine, 21 (3), 35.

23. Klein, E. (2002, January 14) Better Days Ahead for the Local Travel Industry. Focus on Business and Personal Travel, pp. 11-12. 
24. Schwab, Kristin. “Advertisers Are Trying to Adapt to COVID-19.” Marketplace, 5 Apr. 2020, www.marketplace.org/2020/04/03/advertisers-are-trying-adapt-covid19/.

25. Mike Allen. (2010, May 19) American Airlines Post-9/11 Campaign. Retrieved from http://wmw.mikeallenwrites.com/americanairlines-post-911-campaign/(accessed April 2020)

26. TheWrap. (February 25, 2020) Leading cable news networks in the United States in February 2020, by number of total day viewers (in thousands) [Graph]. In Statista. Retrieved May 09, 2020, from https:// wmw.statista.com/statistics/409313/ cable-newsnetwork-total-day-viewers-usa/ (accessed Mar 2020)

27. Ellefson, L. (2020, February 25) February Cable News Ratings: Fox News Posts Best Primetime Numbers Ever. Retrieved from https:/ / www.thewrap.com/february-cable-news-ratings-fox-news-posts-best-primetime-numbers-ever/ (accessed Mar 2020)

28. McAteer, O. (2020, March 27) Coke goes big with COVID social distancing in Times Square. Retrieved from bttps:/ / www.campaignlive.com/ article/ coke-goes-big-covid-social-distancing-times-square/ 1677909 (accessed April 2020)

29. Gartner, Inc. (n.d.) How Active Are Activewear Brands in the Fight against COVID-19. Retrieved from https:/ / wmw.gartner.com/en/marketing/insights/daily-insights/ how-active-are-activewear-brands-in-the-fight-against-covid-19 (accessed April 2020)

30. Dasgupta, S. (2020, April 18) Stay home: Honda promotes Covid-19 awareness with this homemade Civic commercial. Retrieved from https:/ / auto.hindustantimes.com/ auto/news/stay-home-honda-promotes-covid-19-awareness-with-this-homemade-civiccommercial-41587186158063.html (accessed April 2020)

31. Today Show. (2020, March 24). McDonald's gives its famous logo a makeover to promote social distancing. Retrieved from https:/ / www.today.com/food/ mcdonald-s-changes-golden-arches-logo-amid-coronavirus-outbreak-t176653 (accessed April 2020)

32. Perez, S. (2020, March 25) Spotify adds fundraising features and a COVID-19 news hub to address the health crisis. Retrieved from https:/ / techcrunch.com/2020/03/25/spotify-adds-fundraising-features-and-a-covid-19-news-bub-to-address-the-healthcrisis/(accessed April 2020)

33. American Airlines: You Are Why We Fly. (2020, April 01) Retrieved from https:/ / www.adsoftheworld.com/ media/film/ american_airlines_you_are_why_we_fly?class_Name=collectionlbecontentid=387208 Einline=true\#collection-lb-content (accessed April 2020)

34. Beer, J. (2020, March 17) Ford reads the culture right with new coronavirus response advertising. Retrieved from https:/ / www.fastcompany.com/90478322/ford-reads-the-culture-right-with-new-coronavirus-response-advertising

35. Beer, J. (2020, March 30) 'We're all in this together'? Why brands have so little to say in the pandemic. Retrieved from bttps:/ / www.fastcompany.com/90483063/were-all-in-this-together-why-brands-bave-so-little-to-say-in-the-pandemic (accessed April 2020)

36. Albers-Miller, N. D., Straughan, R. D., \& Prenshaw, P. J. (2007) Advertising travel services to the business traveler. Tourism Management: Analysis, Behaviour and Strategy, 185-196. doi: 10.1079/9781845933234.0185

37. Austin, C. (2012, September 11) These Are The 10 Worst Ads Exploiting The 9/11 Attacks. Retrieved from bttps:/ / www.businessinsider.com/10-ads-exploiting-the-911-attacks-2012-9 (accessed Mar 2020)

38. Elkin, T. (n.d.) Travel Sites Bounce Back After 9/11. Advertising Age.

39. Fitzgerald, K. (n.d.) Travel Finds Its Fleet. Advertising Age.

\section{ABOUT STUDENT AUTHOR}

Hannah Gilliam is a recent graduate, May 2020 with a Major in Business Administration with a Marketing Concentration and a French Language Minor. Originally from Columbus, OH, she studied at Spring Arbor University, and throughout her four years worked several internships in Marketing. Her long-term goals include opening her own wedding and events planning company. After graduation she returned to Spring Arbor University to work as the Alumni and Student Relations Coordinator and is enjoying aiding in the development of her alma mater in new marketing strategies.

\section{PRESS SUMMARY}

COVID-19 has severely changed the world and the global economic market. These changes are comparable to the effects of 9/11; people are fearful, anxious, and the future is unknown. After 9/11 the tourism industry had to think quickly to reevaluate the consumer needs and market responses in order to push numbers back up. Because of the similar long-term crisis effects from COVID-19, we can compare the two events to run a predictive analysis on the market response and messaging that will arise in the travel industry. There will perhaps be a theme and direction for messaging within the travel industry post-COVID-19 based on the culture and spirit of The American Dream, confidence in safety, we're in this together, support local tourism, explore your city in a new way, and connect with those you missed. 